\title{
HUBUNGAN POLA MAKAN DENGAN KEJADIAN GASTRITIS PADA PASIEN DI PUSKESMAS PEMBINA PALEMBANG
}

\author{
Muhamad Andika Sasmita Saputra ${ }^{1}$, Ebagustian Tamzil $^{2}$, Murbiah $^{3}$ \\ Program Studi Ilmu Keperawatan, STIKes Muhammadiyah Palembang ${ }^{1}$ \\ Dosen Program Studi Ilmu Keperawatan, STIKes Muhammadiyah Palembang ${ }^{2,3}$
}

Email Corresponding Author : muhamad.andikasp@gmail.com

\begin{abstract}
ABSTRAK
Gastritis merupakan penyakit yang sering dijumpai di masyarakat kita, baik lapisan menengah ke atas maupun lapisan masyarakat menengah ke bawah. Gastritis dapat menyerang setiap orang tanpa mengenal batas usia. Pola makan sehat sangat berguna untuk menjaga kesehatan dan mencegah penyakit, sedangkan pola makan yang salah seperti kelebihan makan atau makan makanan yang kurang seimbang sangat merugikan kita. Belum diketahui Hubungan Pola Makan dengan Kejadian Gastritis pada Pasien di Puskesmas Pembina Palembang. Penelitian ini adalah penelitian Kuantitatif yang dilakukan pada tanggal 10 mei - 5 Juni 2011 dengan desain Analitik Deskriftif dengan pendekatan Cross Sectional dengan teknik pengambilan sampel adalah Non Probability Sampling dan dilakukan dengan Accidental Sampling dengan jumlah sampel 52 responden. Dari hasil Analisis Univariat didapatkan bahwa pasien yang pola makannya sehat $(61,5 \%)$ dan pola makannya tidak sehat $(38,5 \%)$. Pasien yang mengalami kejadian gastritis $(42,3 \%)$ yang tidak mengalami gastritis $(57,7 \%)$. Dari hasil Analisis Bivariat didapatkan bahwa ada hubungan yang signifikan antara pola makan dengan kejadian gastritis pada pasien ( $\mathrm{pValue}=0.020$ ). Hasil ini diharapkan kepada puskesmas mengetahui bahwa masih banyak terdapat pasien yang mengalami gastritis akibat pola makan.
\end{abstract}

Kata Kunci : Pola Makan, Gastritis

\begin{abstract}
Gastritis is a common disease in our society, as the middle and upper strata and sectors of the environment. Gastritis can strike anyone regardless of age restrictions. Healthy eating habits are very useful for the health and disease prevention, while the diet is not the case, such as overeating or eating foods that are less than balanced very bad for us. It is not yet known relationship with Gastritis diet Genesis in patients in Pembina Clinic Palembang. The study of quantitative research conducted by 10 May-5 June 2011 with cross-sectional descriptive design Analytical approach to the methods for probabilistic sampling with random sampling and sampling with a sample size of 52 respondents. The results of the univariate analysis showed that patients with a healthy diet $(61,5 \%)$ and the unhealthy diet $(38,5 \%)$. Patients who have experienced events gastritis $(42,3 \%)$ had no gastritis $(57,7 \%)$. Bivariado analysis of the results that had a significant relationship between the diet and the incidence of gastritis in patients (pValue $=0,020)$. These results are expected in the clinic should know that still a lot of patients who have experienced events gastritis of effect diet.
\end{abstract}

Keyword : Diet, Gastritis

\section{PENDAHULUAN}

Gastritis merupakan penyakit yang sering dijumpai di masyarakat kita, baik lapisan menengah ke atas maupun lapisan masyarakat menengah ke bawah. Gastritis adalah rasa sakit akibat peradangan atau luka di lambung. Gastritis dapat menyerang setiap orang tanpa mengenal batas usia. Gastritis juga dapat muncul secara tiba-tiba dalam waktu yang singkat (akut), waktu yang lama (kronik), atau karena kondisi khusus seperti adanya penyakit lain (Sarasvati, 2010). 
Keluhan gastritis merupakan suatu keadaan yang sering dan banyak dijumpai dalam kehidupan sehari-hari. Tidak jarang kita jumpai penderita gastritis kronis selama bertahun-tahun berobat dari satu dokter ke dokter yang lain untuk mengobati keluhan gastritis yang diderita. Berbagai cara dan usaha mereka lakukan untuk mengobati penyakit gastritisnya sehingga menambah biaya yang dikeluarkan setiap bulan. Bagi penduduk yang berekonomi rendah hal tersebut dapat menimbulkan stress sehingga dapat menambah berat beban biaya yang dikeluarkan dan penyakit gastritis yang dideritanya (Budiana, 2006).

Budiana (2006), mengatakan bahwa gastritis merupakan salah satu penyakit terbesar di dunia dan bahkan diperkirakan diderita lebih dari 1,7 milyar orang. Pada negara berkembang infeksi diperoleh pada usia dini dan pada negara maju sebagian besar dijumpai pada usia tua.

Riyanto (2008), mengatakan bahwa wanita lebih banyak terserang gastritis dibandingkan pria dan wanita dapat terkena penyakit gastritis sejak usia dewasa muda hingga lanjut usia. Badan penelitian kesehatan dunia WHO mengadakan tinjauan terhadap delapan negara dunia dan mendapatkan beberapa hasil persentase dari angka kejadian gastritis di dunia. Dimulai dari negara yang kejadian gastritisnya paling tinggi yaitu Amerika dengan persentase mencapai $47 \%$ kemudian diikuti oleh India dengan persentase $43 \%$, lalu dibeberapa negara lainnya seperti Inggris 22\%, China $31 \%$, Jepang $14,5 \%$, Kanada 35\%, Perancis $29,5 \%$, dan Indonesia 40,8\%. Gastritis biasanya dianggap sebagai suatu hal yang remeh namun gastritis merupakan awal dari sebuah penyakit yang dapat menyusahkan kita (Yorimichi, 2011).

Yorimichi (2011), mengatakan bahwa di Indonesia angka kejadian gastritis cukup tinggi. Dari penelitian dan pengamatan yang dilakukan oleh Departemen Kesehatan RI angka kejadian gastritis dibeberapa kota di Indonesia ada yang tinggi mencapai $91,6 \%$ yaitu di kota Medan, lalu dibeberapa kota lainnya seperti Surabaya 31,2\%, Denpasar 46\%, Jakarta 50\%, Bandung 32,5\%, Palembang $35,3 \%$, Aceh $31,7 \%$, dan Pontianak 31,2\%. Pola makan yang tidak teratur merupakan penyebab seseorang terserang gastritis (Jayanti, 2011). Menurut Herlan (2001) faktor etiologi gastritis lainnya adalah asupan alkohol berlebihan 20\%, merokok $5 \%$, pola makan $15 \%$, obat-obatan $18 \%$ dan terapi radiasi $2 \%$.

Pola makan sehat sangat berguna untuk menjaga kesehatan dan mencegah penyakit, sedangkan pola makan yang salah seperti kelebihan makan atau makan makanan yang kurang seimbang sangat merugikan kita. Dalam beberapa kasus adanya kasus kematian akibat penyakit yang timbul karena pola makan yang salah/tidak sehat belakangan ini cenderung meningkat. Penyakit akibat pola makan yang kurang sehat tersebut diantaranya diabetes mellitus, hiperkolesterolemia, penyakit kanker, penyakit arteri koroner, sirhosis, osteoporosis, penyakit pada sistem pencernaan (gastritis, kanker usus atau kanker kolon), dan beberapa penyakit kardiovaskuler. Bahkan dilaporkan bahwa kematian dini dari penyakit-penyakit di atas $50 \%$ diantaranya karena pola makan yang salah (Wikipedia, 2011).

Gastritis bisa disembuhkan tetapi tidak bisa sembuh total, gastritis adalah penyakit yang dapat kambuh apabila si penderita tidak makan teratur, terlalu banyak makan, atau sebab lain. Biasanya untuk meredakan atau menyembuhkannya penderita harus meminum obat. Tetapi gastritis dapat di cegah, yaitu dengan cara menerapkan pola makan yang sehat, makan teratur, makan secukupnya, cuci tangan sebelum makan. Jadwal makan yang tidak teratur akan membuat lambung sulit beradaptasi (Sarasvati, 2010). Dalam hal ini perlu kita ukur bagaimana hubungan pola makan dengan kejadian gastritis.

Berdasarkan hasil survey di lokasi penelitian di Puskesmas Pembina Palembang jumlah kunjungan pasien gastritis Puskesmas Pembina Palembang rata-rata mencapai \pm 1.263 orang selama 4 tahun terakhir. Data penderita gastritis yang berobat selama empat tahun terakhir pada tahun 2007 sebanyak 957 orang, tahun 2008 sebanyak 820 orang, tahun 2009 sebanyak 1177 untuk usia dewasa dan 232 orang untuk usia lanjut, serta tahun 2010 sebanyak 919 orang untuk usia dewasa dan 947 orang untuk usia lanjut. Data tahun 2011 pada bulan Januari hingga 
April sebanyak 240 orang (Profil Puskesmas Pembina, 2011).

\section{METODOLOGI PENELITIAN}

Jenis penelitian ini adalah kuantitatif dengan menggunakan metode survei analitik melalui pendekatan Cross Sectional. Rancangan penelitian Cross Sectional yaitu suatu penelitian seksional silang yang semua variabelnya diteliti dalam waktu bersamaan (Setiadi, 2007).

Variabel sebab atau independen dan variabel akibat atau dependen yang terjadi pada objek penelitian diukur dan dikumpulkan secara simultan, sesaat atau satu kali saja dalam satu waktu (waktu yang bersamaan) (Setiadi, 2007). Variabel dependen yaitu kejadian gastritis dan variabel independen yaitu pola makan.

Populasi dalam penelitian ini sebanyak 60 orang yang merupakan ratarata per bulan dari pasien gastritis yang berobat ke Puskesmas Pembina Palembang pada bulan Januari sampai dengan April tahun 2011.

Teknik Pengambilan sampel adalah dengan cara non probality sampling dan dilakukan dengan Acidental Sampling, didasarkan pada pertimbangan tertentu yang dibuat oleh peneliti sendiri, berdasarkan ciri atau sifat-sifat populasi sudah diketahui sebelumnya. Sampel yang diambil adalah pasien yang kebetulan berobat ke Puskesmas Pembina pada bulan Mei 2011. Besar sampel yang diambil adalah 52 orang responden.

Penelitian ini dilaksanakan di Puskesmas Pembina Palembang, dan dilaksanakan pada 10 Mei sampai dengan 5 Juni 2011. Untuk mendapatkan data mengenai hubungan pola makan dengan kejadian gastritis, yaitu dengan melakukan wawancara dan menggunakan kuesioner yang sebelumnya telah diuji validitas terlebih dahulu dan menunjukkan hasil yang reabel. Peneliti memilih kuesioner dengan pertanyaan tertutup sebagai alat pengumpulan data dengan pertimbangan beberapa keuntungan yaitu: mudah mengarahkan jawaban responden, dan juga mudah diolah (Notoatmodjo, 2002).

Analisis univariat bertujuan untuk mendeskripsikan masing-masing variabel yaitu variabel independen; pola makan dan variabel dependen yaitu kejadian gastritis. Variabel pola makan apabila jawaban responden $\geq 75 \%$ maka pola makannya di kategorikan sehat dan apabila jawaban responden $<75 \%$ maka di kategorikan tidak sehat. Sedangkan variabel kejadian gastritis menghasilkan distribusi dan persentase.

Analisis bivariat dilaksanakan untuk mendapatkan nilai kemaknaan hubungan (korelasi) antara variabel independen dengan variabel dependen. Uji statistik yang digunakan untuk menguji data kategorik pada penelitian ini dilakukan dengan uji Chi Square dengan derajat kepercayaan $95 \%$ atau alpha 0,05. Jika $\mathrm{p}$ Value $<0,05$ maka $\mathrm{H}_{\mathrm{o}}$ ditolak artinya ada hubungan antara variabel independen dengan variabel dependen.

\section{HASIL PENELITIAN}

\section{Gambaran Karakteristik Responden}

Gambaran karakteristik responden dilakukan untuk mengetahui gambaran distribusi frekuensi responden yang telah dilaksanakan dalam penelitian.

\section{Jenis Kelamin}

Tabel 1. Distribusi frekuensi responden menurut jenis kelamin di Puskesmas Pembina Palembang Tahun 2011

\begin{tabular}{ccc}
\hline $\begin{array}{c}\text { Jenis } \\
\text { Kelamin }\end{array}$ & Jumlah & Persentase \\
\hline Laki-laki & 23 orang & 44,2 \\
Perempuan & 29 orang & 55,8 \\
\hline Jumlah & 52 orang & 100 \\
\hline
\end{tabular}

Berdasarkan tabel 1 di atas dapat diketahui bahwa dari 52 orang responden terdapat 23 orang responden $(44,2 \%)$ berjenis kelamin laki-laki lebih sedikit bila dibandingkan dengan responden yang berjenis kelamin perempuan yaitu 29 orang responden $(55,8 \%)$.

\section{Usia}

Tabel 2. Distribusi frekuensi responden menurut usia di Puskesmas Pembina Palembang Tahun 2011

\begin{tabular}{ccc}
\hline Usia & Jumlah & Persentase \\
\hline Dewasa $\leq 60$ & 44 orang & 84,6 \\
Lansia $>60$ & 8 orang & 15,4 \\
\hline Jumlah & 52 orang & 100 \\
\hline
\end{tabular}


Berdasarkan tabel 2 di atas dapat diketahui bahwa dari 52 orang responden terdapat 44 orang responden $(84,6 \%)$ berusia dewasa lebih banyak bila dibandingkan dengan responden lansia yaitu 8 orang responden $(15,4 \%)$.

\section{Pendidikan}

Tabel 3. Distribusi frekuensi responden menurut pendidikan di Puskesmas Pembina Palembang Tahun 2011

\begin{tabular}{lcc}
\hline Pendidikan & Jumlah & Persentase \\
\hline SMP & 8 orang & 15,4 \\
SMA & 44 orang & 84,6 \\
\hline Jumlah & 52 orang & 100 \\
\hline
\end{tabular}

Berdasarkan tabel 3 di atas dapat diketahui bahwa dari 52 orang responden terdapat 8 orang responden $(15,4 \%)$ berpendidikan SMP lebih sedikit bila dibandingkan dengan responden yang berpendidikan SMA yaitu 44 orang responden $(84,6 \%)$.

4. Pekerjaan

Tabel 4. Distribusi frekuensi responden menurut pekerjaan di Puskesmas Pembina Palembang Tahun 2011

\begin{tabular}{lcc}
\hline \multicolumn{1}{c}{ Pekerjaan } & Jumlah & Persentase \\
\hline Tidak Bekerja & 6 orang & 11,5 \\
Buruh & 12 orang & 23,1 \\
Pedagang & 4 orang & 7,7 \\
Swasta & 5 orang & 9,6 \\
PNS & 5 orang & 9,6 \\
Ibu Rumah Tangga & 20 orang & 38,5 \\
\hline \multicolumn{1}{c}{ Jumlah } & 52 orang & 100
\end{tabular}

Berdasarkan tabel 4 di atas dapat diketahui bahwa dari 52 orang responden terdapat 20 orang responden $(38,5 \%)$ yang bekerja sebagai ibu rumah tangga, sedangkan 12 orang responden $(23,1)$ bekerja sebagai buruh, 6 orang responden $(11,5 \%)$ tidak bekerja, 5 orang responden $(9,6 \%)$ bekerja swasta, 5 orang responden $(9,6 \%)$ bekerja sebagai PNS, serta 4 orang responden $(7,7 \%)$ bekerja sebagai pedagang.

\section{Hasil Analisis Univariat}

Analisis Univariat dilakukan untuk mengetahui gambaran distribusi frekuensi yang dilaksanakan tiap-tiap variabel dari hasil penelitian.

1. Pola Makan

Variabel pola makan yaitu jawaban responden yang $\geq 75 \%$ maka pola makannya di kategorikan sehat dan jawaban responden $<75 \%$ maka di kategorikan tidak sehat.

Tabel 5. Distribusi frekuensi responden menurut pola makan di Puskesmas Pembina Palembang Tahun 2011

\begin{tabular}{lcc}
\hline \multicolumn{1}{c}{ Pola Makan } & Jumlah & Persentase \\
\hline Sehat & 32 orang & 61,5 \\
Tidak Sehat & 20 orang & 38,5 \\
\hline \multicolumn{1}{c}{ Jumlah } & 52 orang & 100 \\
\hline
\end{tabular}

Berdasarkan tabel 5 di atas dapat diketahui bahwa dari 52 orang responden terdapat 32 orang responden $(61,5 \%)$ pola makannya sehat lebih besar bila dibandingkan dengan responden yang pola makannya tidak sehat yaitu sebanyak 20 orang responden $(38,5 \%)$.

\section{Kejadian Gastritis}

Tabel 6. Distribusi frekuensi responden berdasarkan kejadian gastritis di Puskesmas Pembina Palembang Tahun 2011

\begin{tabular}{lcc}
\hline $\begin{array}{c}\text { Kejadian } \\
\text { Gastritis }\end{array}$ & Jumlah & Persentase \\
\hline Ya & 22 orang & 42,3 \\
Tidak & 30 orang & 57,7 \\
\hline \multicolumn{1}{c}{ Jumlah } & 52 orang & 100 \\
\hline
\end{tabular}

Berdasarkan tabel 6 dapat diketahui bahwa dari 52 orang responden terdapat 22 orang responden $(42,3 \%)$ mengalami kejadian gastritis lebih sedikit bila dibandingkan dengan responden yang tidak terkena gastritis yaitu sebanyak 30 orang responden $(57,7 \%)$.

\section{Hasil Analisis Bivariat}

Analisis Bivariat dilakukan untuk membuktikan ada atau tidaknya hubungan antara veriabel independen (Pola Makan) dengan variabel dependen (kejadian Gastritis) di Puskesmas Pembina Palembang Tahun 2011. 
Tabel 7. Distribusi Hubungan Pola Makan dengan Kejadian Gastritis di Puskesmas Pembina Palembang Tahun 2011

\begin{tabular}{|c|c|c|c|c|c|c|c|}
\hline \multirow{3}{*}{ Pola Makan } & \multicolumn{4}{|c|}{ Kejadian Gastritis } & \multicolumn{2}{|c|}{ Jumlah } & \multirow{3}{*}{ P Value } \\
\hline & \multicolumn{2}{|c|}{ Ya } & \multicolumn{2}{|c|}{ Tidak } & & & \\
\hline & n & $\%$ & $\mathbf{n}$ & $\%$ & $\mathbf{n}$ & $\%$ & \\
\hline Sehat & 9 & 28,1 & 23 & 71,9 & 32 & 100 & \\
\hline Tidak Sehat & 13 & 65 & 7 & 35 & 20 & 100 & 0,020 \\
\hline Total & 22 & 42,3 & 30 & 57,7 & 52 & 100 & \\
\hline
\end{tabular}

Berdasarkan tabel 7 di atas dapat diketahui hasil analisis hubungan pola makan dengan kejadian gastritis pada pasien di Puskesmas Pembina Palembang tahun 2011 diperoleh bahwa ada sebanyak 9 orang responden $(28,1 \%)$ dari 32 orang responden yang pola makannya sehat mengalami kejadian gastritis, sedangkan diantara responden yang pola makannya tidak sehat ada 13 orang responden $(65 \%)$ dari 20 orang responden yang mengalami kejadian gastritis. Hasil uji statistik $C h i$ Square diperoleh nila $\mathrm{p}$ value adalah $\mathrm{p}=$ 0,020, maka secara statistik dapat dikatakan terdapat hubungan pola makan dengan kejadian gastritis pada pasien di Puskesmas Pembina Palembag tahun 2011.

\section{Pola Makan}

\section{PEMBAHASAN}

Berdasarkan hasil penelitian didapatkan bahwa dari 52 orang responden terdapat 32 orang responden $(61,5 \%)$ pola makannya sehat lebih besar bila dibandingkan dengan responden yang pola makannya tidak sehat yaitu sebanyak 20 orang responden $(38,5 \%)$.

Hasil ini sejalan dengan penelitian yang dilakukan oleh Fitriyani (2003) yang berjudul "Hubungan pola makan dengan kejadian gastritis pada pasien di RS. H. Adam Malik Medan Tahun 2003", dengan hasil dari 76 orang responden terdapat 47 orang responden $(61,8 \%)$ pola makannya sehat.

Hasil ini tidak sejalan dengan hasil penelitian yang dilakukan oleh Putri (2005) dalam penelitiannya yang berjudul "Hubungan Pola Makan dengan Timbulnya Gastritis pada
Pasien di Medical Center (UMC) Universitas Muhammadiyah Malang",

dengan hasil dari 80 orang responden terdapat 42 orang responden $(52,5 \%)$ pola makannya tidak sehat lebih besar bila dibandingkan dengan responden yang pola makannya sehat yaitu 38 orang responden $(47,5 \%)$. Hasil ini juga tidak sejalan dengan penelitian yang dilakukan oleh Daniati (2006) dalam penelitiannya yang berjudul "Hubungan Pola Makan dengan Timbulnya Gastritis pada Pasien di Ruang Penyakit Dalam RSUD. DR. Moewardi Surakarta Tahun 2006", dengan hasil dari 90 orang responden terdapat 47 orang responden $(52,3 \%)$ pola makannya tidak sehat lebih besar bila dibandingkan dengan responden yang pola makannya sehat yaitu 43 orang responden (47,7\%). Belum mampunya responden menerapkan pola makan sehat bisa menjadi penyebab perbedaan hasil penelitian ini.

Pola makan sehat sangat penting bagi tubuh kita karena dalam sehari tubuh kita membutuhkan zat gizi untuk menunjang aktifitas yang kita kerjakan sehari-hari, selain itu pola makan sehat juga dapat mempengaruhi ketahanan fisik sesorang dan menghindarkan kita dari penyakit. Hal ini sesuai dengan teori yang diungkapkan oleh Hardani (2002), yang mengatakan bahwa pola makan sehat sangat penting karena pola makan sehat memiliki dampak yang sangat baik pada tubuh, kondisi fisik tubuh akan lebih terjamin sehingga tubuh akan dapat melakukan aktifitasnya dengan baik. Dengan 
tubuh yang sehat, orang akan lebih bersemangat untuk bekerja, berpikir dan akan lebih produktif. Hal ini karena kebutuhan tubuh dapat dipenuhi dengan baik sehingga organorgan tubuh akan melakukan fungsinya dengan baik. Namun sebaliknya, pola makan yang buruk akan berdampak buruk pula bagi tubuh kita, bila tubuh kekurangan suatu zat gizi tertentu, maka daya tahannya juga akan menurun. Kemampuan kerjanya melemah, dan bila berkelanjutan akan dapat menimbulkan penyakit yang berbahaya.

Belum terlaksananya pola makan sehat pada beberapa reponden dalam penelitian ini bisa dikaitkan dengan beberapa faktor seperti kebiasaan atau aktifitas sehari-hari yang dikerjakan oleh responden sehingga menyebabkan responden tersebut kurang memperhatikan pola makan yang ia terapkan, disisi lain juga ada faktor budaya, agama, serta status ekonomi, dan status kesehatan yang bisa mempengaruhi penurunan nafsu makan responden. Hal ini sesuai dengan teori yang dikemukakan oleh Healthzone (2009), yang mengatakan bahwa ada beberapa faktor yang dapat mempengaruhi pola makan antara lain faktor budaya, agama/kepercayaan, status sosial ekonomi, personal preference, rasa lapar, nafsu makan, rasa kenyang, dan kesehatan. Teori yang sama juga di ungkapkan oleh Irianto \& Waluyo (2004) yang mengatakan bahwa pola konsumsi makanan seseorang dipengaruhi oleh berbagai faktor, diantaranya : sosial, ekonomi, lingkungan, budaya seperti kebiasaan, kepercayaan, dan adat.

\section{Kejadian Gastritis}

Berdasarkan hasil penelitian didapatkan bahwa dari 52 orang responden terdapat 22 orang responden $(42,3 \%)$ mengalami kejadian gastritis lebih sedikit bila dibandingkan dengan responden yang tidak terkena gastritis yaitu sebanyak 30 orang responden $(57,7 \%)$.

Hasil ini tidak sejalan dengan hasil penelitian Putri (2005) dalam penelitiannya yang berjudul "Hubungan Pola Makan dengan
Timbulnya Gastritis pada Pasien di Medical Center (UMC) Universitas Muhammadiyah Malang", dengan hasil dari 80 orang responden terdapat 47 orang responden $(58,7 \%)$ mengalami kejadian gastritis lebih besar bila dibandingkan dengan responden yang tidak mengalami kejadian gastritis yaitu 33 orang responden $(41,3 \%)$. Hasil ini juga tidak sejalan dengan penelitian yang dilakukan oleh Daniati (2006) dalam penelitiannya yang berjudul "Hubungan Pola Makan dengan Timbulnya Gastritis pada Pasien di Ruang Penyakit Dalam RSUD. DR. Moewardi Surakarta tahun 2006", dengan hasil dari 90 orang responden terdapat 46 orang responden $(51,1 \%)$ mengalami kejadian gastritis lebih besar bila dibandingkan dengan responden yang tidak mengalami kejadian gastritis yaitu 44 orang responden $(48,9 \%)$. Ada faktor dan hal-hal lain yang bisa menyebabkan kejadian gastritis pada responden sehingga menyebabkan perbedaan dari hasil penelitian ini.

Masih adanya responden yang mengalami kejadian gastritis dalam penelitian ini bisa disebabkan oleh faktor psikologis dan hal-hal lain seperti adanya gangguan lambung, serta reaksi terhadap obatobatan suplemen. Hal ini di kemukakan oleh Sugani dan Priandarini (2010) yang mengatakan bahwa hal-hal yang umumnya dapat menyebabkan terjadinya gastritis adalah reaksi terhadap obat-obatan suplemen, produksi asam lambung berlebihan, gangguan lambung, kepekaan terhadap asam, peka terhadap makanan tertentu, reaksi berlebihan terhadap rangsangan normal, stres dan faktor psikologis lain. Sedangkan menurut Sarasvati (2010) hal-hal yang umumnya dapat menyebabkan terjadinya gastritis adalah gangguan fungsi lambung, gangguan struktus anatomi yang bisa berupa luka, jadwal makan yang tidak teratur, konsumsi alkohol atau kopi yang berlebihan, gangguan stres, merokok, pemakaian obat penghilang nyeri dalam jangka panjang dan secara terus menerus, stres fisik akibat pembedahan besar atau infeksi berat 
yang dapat menyebabkan gastritis, dan terakhir yaitu infeksi bakteri Helicobacter Pylori.

Gastritis merupakan peradangan pada lambung dan bila hal ini terus berkelanjutan akan berdampak buruk pada organ lambung, selain itu juga bisa menyebabkan penyakit lain seperti kanker lambung. Hal ini dikemukakan oleh Masjoer (2000), yang mengatakan bahwa gatritis akan menyebabkan resiko kanker lambung terutama jika terjadi penipisan secara terus menerus pada dinding lambung dan perubahan pada sel-sel pada dinding lambung, selain itu sekresi asam lambung berlebihan juga akan menimbulkan komplikasi yaitu tukak lambung.

3. Analisis Bivariat Hubungan Pola Makan Dengan Kejadian Gastritis Berdasarkan hasil penelitian didapatkan bahwa ada hubungan pola makan dengan kejadian gastritis pada pasien di Puskesmas Pembina Palembag tahun 2011

Hasil penelitian ini sejalan dengan penelitian yang dilakukan oleh Putri (2005) dengan hasil penelitian yaitu terdapat hubungan pola makan dengan timbulnya gastritis pada pasien di Medical Center (UMC) Universitas Muhammadiyah Malang. Hasil ini juga sejalan dengan penelitian yang dilakukan oleh Daniati (2006) dengan hasil penelitian yaitu terdapat hubungan pola makan dengan kejadian gastritis pada pasien di Ruang Penyakit Dalam RSUD. DR. Moewardi Surakarta. Begitu pula dengan hasil penelitian yang dilakukan oleh Fitriyani (2003) dengan hasil ada hubungan pola makan dengan kejadian gastritis pada pasien di RS. H. Adam Malik Medan.

Pola makan yang buruk dapat menyebabkan terjadinya gastritis karena pola makan yang buruk, berlebihan dan tak teratur akan mengakibatkan meningkatnya pengeluaran cairan lambung. Sebaliknya pola makan yang sehat akan berdampak sangat baik pada tubuh, kondisi fisik tubuh akan lebih terjamin sehingga tubuh akan dapat melakukan aktifitasnya dengan baik. Dengan tubuh yang sehat, orang akan lebih bersemangat untuk bekerja, berpikir dan akan lebih produktif. Hasil ini sejalan dengan teori yang dikemukakan oleh Sarasvati (2010) bahwa pola makan yang buruk dapat menyebabkan resiko seseorang terkena penyakit gastritis, hal ini juga dikemukakan oleh Jayanti (2011) bahwa pola makan yang dapat menyebabkan terjadinya gastritis yaitu waktu makan yang tidak teratur dan kandungan makanan atau jenis makanan yang dimakan. Ada beberapa jenis makanan yang sebaiknya di kurangi untuk dikonsumsi terutama makanan yang pedas dan mengandung lemak berlebihan. Hal ini juga dikemukakan oleh Escasia (2009) yang mengatakan bahwa makanan yang sebaiknya kita kurangi atau tidak berlebihan untuk mengkonsumsinya antaralain : nasi goreng, bakmi goreng, bihun goreng, jerohan (hati, usus, babat, paru, otak, limpa), santan, goreng-gorengan, daging merah, mie instan, gula pasir dan olahannya (gula pasir, gula merah, permen, gulali, sirup), pemanis buatan (silamat, sakarin, dan aspartam), makanan dan minuman kaleng instan (yang diawetkan), vetsin dan msg, coklat, soft drink dan minuman bersoda, alkohol, susu sapi full cream, camilan asin, daging olahan (kornet, sosis, bakso, daging asap), kuning telur dan telur puyuh, keju olahan dan pasta, kue-kue manis, fast food, kacang goreng, mayonaise. Makanan tersebut dapat berakibat buruk untuk kesehatan dan pencernaan terutama lambung karena dapat meningkatkan asam lambung.

Makanan yang sebaiknya kita konsumsi adalah makan yang mengandung protein, karbohidrat, vitamin serta mineral yang terkandung dalam makanan pokok empat sehat loma sempurna. Hal ini dikemukakan oleh Siswono (2002), Pola makan yang dianjurkan yaitu berasal dari karbohidrat $60-70 \%$ yang dapat menghasilkan energi, dari protein 15$20 \%$, dan dari lemak 20-30\%, serta cukup vitamin, mineral dan serat. Hal ini juga dikemukakan oleh Escasia 
(2009) yang mengatakan bahwa makanan yang sebaiknya kita makan adalah makanan yang mengandung Karbohidrat seperti beras merah, oatmeals, havermut, roti gandum, baked potato, mash potato, semangka, jambu biji, lemon. Protein seperti ikan bakar, ayam bakar (dada \& tanpa kulit), telur (tanpa kuning), tempe, tahu, tuna, salmon. Buah-buahan yang baik untuk dikonsumsi yaitu pisang, jeruk, pepaya, mangga, apel, sirsak, melon, strawberry, belimbing, timun. Sayur-sayuran yang baik untuk dikonsumsi yaitu selada, brokoli, wortel, buncis, tomat, jagung, sawi, bayam, kangkung, toge, kailan. Dan myang termasuk jenis susu/yogurt seperti susu kedelai, yogurt low fat, olive oil/minyak zaitun, mentega, madu alami, crakers/plain, kismis.

Melihat dari dampak buruk akibat penyakit gastritis untuk menghindarinya ada hal-hal lain juga yang perlu diperhatikan seperti mengatur pola makan, menjaga porsi makan sesuai dengan kebutuhan tubuh. Hal ini dikemukakan oleh Sarasvati (2010) yang mengatakan bahwa untuk menghindari gejala komplikasi lanjut yaitu dengan cara makan teratur dengan porsi makan sesuai dengan kebutuhan tubuh, bila merasa lapar tetaplah makan walau di luar jam makan, jika nafsu makan menurun tingkatkan porsi makan dengan porsi kecil, mencoba mengkonsumsi makanan ringan yang bergizi misalnya sayuran segar, sereal, buah segar, juas buah. Kemudian hindari kondisi stres dan pikiran tegang, membangun suasana makan yang menyenangkan, memvariasikan makanan dan mencoba resep-resep baru yang menarik, menyediakan stok bahan-bahan makanan yang mudah dan cepat dibuat, tetap minum obatobat lambung yang di resepkan dokter. Cara lain yaitu dengan makan makanan berserat, berolah raga teratur, minum yang banyak 1,5 hingga 2 liter per hari, kontrol stres, dan kurangi makanan pedas, berlemak serta makanan berminyak.
Dalam penelitian yang berjudul "Hubungan Pola Makan Dengan Kejadian Gastritis pada Pasien di Puskesmas Pembina Tahun 2011", kesimpulan yang dapat diambil sebagai berikut:

1. Diketahui bahwa dari 52 orang responden terdapat 32 orang responden $(61,5 \%)$ pola makannya sehat lebih besar bila dibandingkan dengan responden yang pola makannya tidak sehat yaitu sebanyak 20 orang responden $(38,5 \%)$.

2. Diketahui bahwa dari 52 orang responden terdapat 22 orang responden $(42,3 \%)$ mengalami kejadian gastritis lebih sedikit bila dibandingkan dengan responden yang tidak terkena gastritis yaitu sebanyak 30 orang responden $(57,7 \%)$.

3. Diketahui bahwa ada hubungan pola makan terhadap kejadian gastritis pada pasien di Puskesmas Pembina Tahun 2011.

\section{DAFTAR PUSTAKA}

2007. Konsep \& Penulisan Riset Keperawatan. Yogyakarta: Graha Ilmu.

2009. Konsep dan Penerapan Metodologi Penelitian Ilmu Keperawatan, Edisi 2, Pedoman Skripsi, Tesis, dan Instrumen Penelitian Keperawatan. Jakarta: Salemba Medika. 2004. Metodologi Penelitian Kesehatan. Jakarta: Rineka Cipta.

2010. Ilmu Perilaku

Kesehatan. Jakarta: Rineka Cipta. 2010. Metodologi Penelitian Kesehatan. Jakarta: Rineka Cipta.

Arikunto, Suharsimi. 2006. Prosedur Penelitian Suatu tindakan Praktik. Edisi Revisi VI. Jakarta: Rineka Cipta.

Brunner \& Suddrath. 2002. Buku Ajar Keperawatan Medikal Bedah, Volume 2, Edisi 8. Jakarta: EGC.

Budiana. 2006. Pantangan Makan Penderita Maag. (http://draysay.blogspot.com/2009/04/pantang an-makan-penderita-maag.html, diakses 31 Maret 2011). 
Charlene. 2001. Gastritis yang Terjadi pada Kita. (http://www.epilepsyontario.org/clie nt/EO/EOWeb.nsf/web/Lifestyle, diakses 28 desember 2010).

Dahlan, M. Sopiyudin. 2009. Statistik untuk Kedokteran dan Kesehatan, Deskriptif, Bivariat, dan Multivariat Dilengkapi Aplikasi dengan Menggunakan SPSS, edisi 4. Jakarta: Salemba Medika.

Daniati, Renyta Rima. 2006. Hubungan Pola Makan dengan timbulnya Gastritis pada Pasien di Ruang Penyakit Dalam RSUD. DR. Moewardi Surakarta Tahun 2006.

Depkes RI. 2002. Pola Makan dan Gastritis.

(http://Farmasiku.com/maag-polamakan.html, akses 31 desember 2010).

Escasia. 2009. Pola Makan yang Baik. (http://www.escasia.com/det.php?aid $=9 \& p g=6 \& \mathrm{~nm}=$

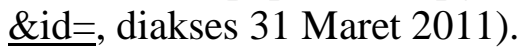

Evelyn, C. Pearce. 2009. Anatomi dan Fisiologi Untuk Paramedis. Jakarta: Gramedia Pustaka Utama.

Fikrirasyid. 2008. Tips Pola Makan yang Sehat: Ternyata Pola Makan Tiga Kali Sehari Kurang Bagus. (http://fikrirasyid.com/tips-pola$\underline{\text { makan-yang-sehat-ternyata-pola- }}$ makan-tiga-kali-sehari-kurangbagus, diakses 31 Maret 2011).

Fitriyani. 2003. Hubungan Pola Makan dengan Kejadian Gastritis pada Pasien di RS. H. Adam Malik Medan Tahun 2003.

Grahacendikia. 2009. Hubungan Antara Pola Makan Sehari-Hari Di Rumah Dengan Terjadinya Gastritis Pada Pasien Yang Dirawat di RSUXX. (http://grahacendikia.wordpress.com/ 2009/04/01/hubungan-antara-polamakan-sehari-hari-di-rumah-denganterjadinya-gastritis-pada-pasienyang-dirawat-di-rsu-xx, diakses 10 Desember 2010).

Hardani, Rika. Hasil Seminar Online Kharisma 6-22 Desember 2002. Menjadi Ratu Dapur Profesional; Mengawal Kesehatan Keluarga
Melalui Pemilihan \& Pengolahan Pangan yang Tepat. Jakarta.

Hastono, Sutanto Priyo. 2001. Modul Analisis Data. Jakarta: Fakultas Kesehatan Masyarakat Universitas Indonesia.

Healthzone. 2008. Pola Makan-1. (http://puskesmasoke.blogspot.com/2009/01/polamakan-1.html, diakses 31 Maret 2011).

Herlan. 2001. Pola Makan Teratur dan Tidak Stres Untuk Lambung Sehat. http://lifestyle.okezone.com/read/201 0/11/19/195/395002/makan-teraturtidak-stres-untuk-lambungsehat.html, diakses 18 Desember 2010).

Heryati, dkk. 2011. Pola Makan Sehat dan Tehnik Mengukur Pola Makan Dalam Penelitian. (http://lopsky.blogspot.com/2011/06/ pola-makan-sehat-dan-tehnikmengukur.html), diakses 4 April 2011.

Hidayat, Aziz Alimul. 2009. Metode Penelitian Keperawatan dan Teknik Analisa Data. Jakarta: Salemba Medika.

Irianto, Kus \& Waluyo, Kusno. 2004. Gizi dan Pola Hidup Sehat. Bandung: Yrama Widya.

Jayanti, Uci. Solusi Tepat Mengatasi Maag. Sumatera Ekspres, 11 April 2011, hlm 6, kolom 7 .

Lanywati, Endang. 2001. Penyakit Maag dan Gangguan Pencernaan. Yogyakarta: Kanisius.

Lynda. 2010. Pola Makan yang baik untuk penderita gastrtis. (http://thiuzthiuz.blogspot.com/2010/ 10/manfaat-makanan-4-sehat-5sempurna.html, diakses 10 Januari 2011)

Machfoedz, Ircham. 2008. Teknik Membuat Alat Ukur Penelitian Bidang Kesehatan, Kedokteran, Keperawatan, dan Kebidanan. Yogyakarta: Fitramaya.

Mansjoer, Arif. 2000. Kapita Selekta Kedokteran, Jilid 2. Jakarta: FKUI. 
Mustakim. 2009. Pola Dan Jenis Makanan Penderita Gastritis (http://www.pdpersi.co.id/?show=isi $\underline{\text { konsul\&konsul=gizi\&kode }=7 \& \mathrm{tbl}=\mathrm{k}}$ onsul_gizi\&startnews $=10$, diakses 13 Januari 2011).

Notoatmdjo, Soekidjo. 2002. Metodologi Penelitian Kesehatan. Jakarta: Rineka Cipta.

Nursalam. 2008. Konsep dan Penerapan Metodologi Penelitian Ilmu Keperawatan, Edisi 2. Pedoman skripsi, Tesis, dan Instrumen Penelitian Keperawatan. Jakarta: Salemba Medika.

Paath, Rumdasih, \& Heryati. 2004. Gizi Dalam Kesehatan Reproduksi. Jakarta: EGC.

Puskesmas Pembina. 2011. Profil Puskesmas Pembina 2011. Palembang.

Putri, Rona Sari Mahaji. 2005. Hubungan Pola Makan dengan Timbulnya Gastritis pada Pasien di Medical Center (UMC) Universitas Muhammadiyah Malang.

Reevest, Charlene. J. 2001. Keperawatan Medikal Bedah, Edisi 1. Jakarta: Salemba Medika.

Riwidikdo, Handoko. 2009. Statistik Kesehatan, Belajar Mudah Teknik Analisis Data dalam Penelitian Kesehatan (Plus Aplikasi Software SPSS). Yogyakarta: Mitra Cendikia Press.

Robbins. 2004. Makan Teratur, Kunci Pola Hidup Sehat. (http://paperlessmedia.blogspot.com/2008/11/makanteratur-kunci-pola-hidup-sehat.html, diakses 21 Desember 2010).

Sarasvati, Tim. 2010. Mini Seri Self Healing Cara Holistik \& Praktis Atasi Maag. Jakarta: Bhuana Ilmu Populer.

Sediaoetama, Achmad Djaeni. 2009. Ilmu Gizi Untuk Mahasiswa dan Profesi di Indonesia, Jilid II. Jakarta: Dian Rakyat

Setiadi. 2007. Anatomi dan Fisiologi Manusia. Yogyakarta: Graha Ilmu.

Siswono. 2002. Kembali ke Pola Makan yang

Benar. (http://www.gizi.net/cgibin/berita/fullnews.cgi?newsid10412 19513,57968, diakses 31 Maret 2011).

Sloane, Ethel. 2004. Anatomi dan Fisiologi Untuk Pemula. Jakarta: EGC.

Snell, Richard S. 2006. Anatomi Klinik Untuk mahasiswa Kedokteran, Edisi 6. Jakarta: EGC.

Sudoyo, Aru W. 2007. Buku Ajar Ilmu Penyakit Dalam. Jakarta: FKUI.

Sugani, Surya. \& Priandarini, Lucia. 2010. Cara Cerdas Untuk Sehat: Rahasia Hidup sehat Tanpa Dokter. Jakarta: Transmedia Pustaka.

Suyono. 2001. Laporan Pendahuluan Gastritis.

(http://tutorialkuliah.onsugar.com/La poran-Pendahuluan-Gastritis13747989, diakses 29 desember 2010)

Wikipedia. 2011.2 Maag. (http://wikipedia.id/maag.html, diakses 14 Januari 2011).

Yorimichi. 2011. Pola Makan dalam Kehidupan Orang-orang yang Terkena Gastritis. (http://lopsky.blogspot.com/2011/04/ pola-makan-dalam-kehidupan-orangorang.html, diakses 22 April 2011).

Yuliarti, Nurheti. 2009. Maag - Kenali, Hindari, dan Obati. Yogyakarta: Andi Offset. 